Original Research

\title{
The Effectiveness of Auditory Stimuli from Murottal Quran to Improve Comfort and Weight in Low Birth Weight Infants: Randomized Controlled Trial
}

\section{Desriati Devi, Yuni Rustina and Defi Efendi}

Department of Child, Faculty of Nursing, Universitas Indonesia, West Java, Indonesia

\section{ABSTRACT}

Introduction: Low birth weight (LBW) infants who have been hospitalized are exposed to various conditions that provoke discomfort, which could trigger a stress response and growth disorders. This study aimed to identify the effects of auditory stimuli from Murottal Quran when it comes to the comfort and weight of LBW infants.

Methods: This study used a clinical randomized controlled trial design involving 52 low birth weight infants. The infants were randomly assigned to either the intervention group $(n=26)$ or the control $(n=26)$. The intervention of Murottal Quran was given using a speaker 4 times a day for 20 minutes every 3 hours. This intervention was conducted for three days.

Results: The results of this study show that there is a significant difference in the comfort of low birth weight infants after Murottal Qur'an on the first, second, and third days between the intervention and control groups $(\mathrm{p}=0.014 ;<0.001$; $<0.001$ ). There was no significant difference in the weight between the intervention and control groups in the first, second, and third days $(p=0.481$; $0.481 ; 0.464$ ).

Conclusion: The auditory stimuli of Murottal Quran can help to improve the comfort level of low birth weight infants during hospitalization. It can therefore be used as a supportive therapy to facilitate low birth weight infant and premature infant development.

\section{ARTICLE HISTORY}

Received: August 13, 2019

Accepted: December 16, 2019

\section{KEYWORDS}

Murottal quran; comfort; weight, low birth weight infants

\section{CONTACT}

\section{Yeni Rustina}

$\triangle$ y_rustina@ui.ac.id

$\doteqdot$ Department of Child,

Faculty of Nursing,

Universitas Indonesia, West

Java, Indonesia

Cite this as: Devi, D, Rustina, Y, and Efendi, D. (2019). The Effectiveness of Auditory Stimuli from Murottal Quran to Improve Comfort and Weight in Low Birth Weight Infants: Randomized Controlled Trial. Jurnal Ners, 14(1), 111-117. doi:http://dx.doi.org/10.20473/jn.v14i1.14823

\section{INTRODUCTION}

Hospitalized infants exposed to diverse environmental stressors can experience negative effects (Majidipour et al., 2018; Boxwell, 2010). Environmental stress from varied medical devices and procedures causes discomfort in neonates (Bouza, 2009). The increased stress response can lead to acute or prolonged effects (Anderson \& Patel, 2018; Hall \& Sanders, 2018).

The stress response to physiological function could increase the risk of growth disorders, abnormal sleep patterns, hearing disorders, and developmental delay (Almadhoob \& Ohlsson, 2015). Loud sounds from medical devices could disrupt the respiratory system, affect oxygen consumption, cause an irregular heartrate (Brown, 2009; Wachman \& Lahav, 2011) and increase the energy consumption of hospitalized infants (Wachman \&
Lahav, 2011). This could disrupt their growth (Valizadeh, Hosseini, Alavi, Asadollahi, \& Kashefimehr, 2013; Wachman \& Lahav, 2011). In one such study, Pickler et al. (2013) showed that environmental stressors, like loud sounds, increased their nutritional intake compared to loud sound. This could disrupt the optimal nutritional fulfillment of hospitalized infants.

One of the auditory stimuli that could be performed to reduce the stress response in neonates is Murottal therapy, i.e. Quran recitation (Majidipour et al., 2018). Murottal Quran has indicated positive effects on the preterm infants' vital stability (Eskandari et al., 2012; Marofi et al., 2018; Qolizadeh, Myaneh, \& Rashvand, 2018). It has been found to reduce their pain response during treatment in a Neonatal Intensive Care Unit (Marofi et al., 2018). According to Majidipour et al (2018), Murottal could increase the physiological response 


\section{DEVI ET AL.}

in neonates during painful invasive procedures. Another study (Rilla, Ropi, \& Sriati, 2014) showed that Murottal Qur'an had more of an effect when it comes to reducing pain compared to music therapy.

Research studies related to Murottal therapy given to infants in NICU are still very limited, therefore further research is needed as an evidencebased practice for improving the quality of the nursing care provided to neonates. Majidipor et al (2018) and Marofi et al (2018) conducted research to measure the effects of Quran therapy on the physiological response to pain, but they did not look into the effects regarding comfort and weight. This made the writer interested in conducting research in order to identify the effects of auditory stimuli from Murottal Quran on the comfort and weight in LBW infants.

\section{MATERIALS AND METHODS}

This study used a clinical trial incorporating randomization within a controlled trial conducted in parallel between two groups, namely the Murottal Quran intervention group and routine care group. This study was conducted in one of the hospitals in Indonesia from March to May 2019. The number of samples was determined based on the previous study conducted by Qolizadeh et al (2018). The standard deviation for the intervention and control groups was 13.6 and 10.8 respectively where the total respondents for each group was 32 and the combined standard deviation was 12.3 . The researcher set $5 \%$ for error type 1 and $20 \%$ for error type 2 (power $80 \%$ ). The calculation resulted in 50 samples. The number of samples involved in this study was $52 \mathrm{LBW}$ infants who were treated in perinatology. The intervention and control groups were determined through block randomization (block size of four) using a random number table. The sample was chosen according to a random number table based on the sequence of LBWs entering the perinatology. The total sample for each group was $26 \mathrm{LBW}$ infants selected randomly (Figure 1).

The inclusion criteria consisted of: a birth weight of less than 2500 grams, did not have a hearing disorder based on the medical records, did not have congenital anomalies such as a congenital heart defect, not suffering from diarrhea, exhibited a stable physiological function i.e. pulse frequency $120-160$ pulses per minute, respiratory rate 30-60 times per minute and body temperature 36.5-37.5 ${ }^{\circ} \mathrm{C}$ (Rustina, 2015), possible for them to be weighed every day, age of 0-28 days, Muslim, and the mother allowed her baby to be the respondent. The exclusion criteria were the babies who received sedative therapy during the intervention, who exhibited respiratory distress syndrome, and where the mother did not allow her baby to be a respondent.

The outcome from this study focused on comfort and weight. Comfort was measured using the observation sheet of the COMFORTneo scale (van Dijk et al, 2009) consisting of alertness, calmness/agitation, respiratory response, crying, body movement, facial tension, and muscle tone. This instrument has never been used in Indonesia before, therefore the researcher translated it into Indonesian using the Back-translation method. In this study, inter-rater reliability was executed and it involved 3 experts in order to check the agreement among the observers using the COMFORTneo scale. The agreement among the observers showed there to be a strong relationship or reliable based on the Intraclass Correlation Coefficients, i.e. 0.982. This score indicated a very good or very satisfying inter-rater reliability (Koo \& Li, 2016). The weights were measured using digital scales that had been calibrated in advance.

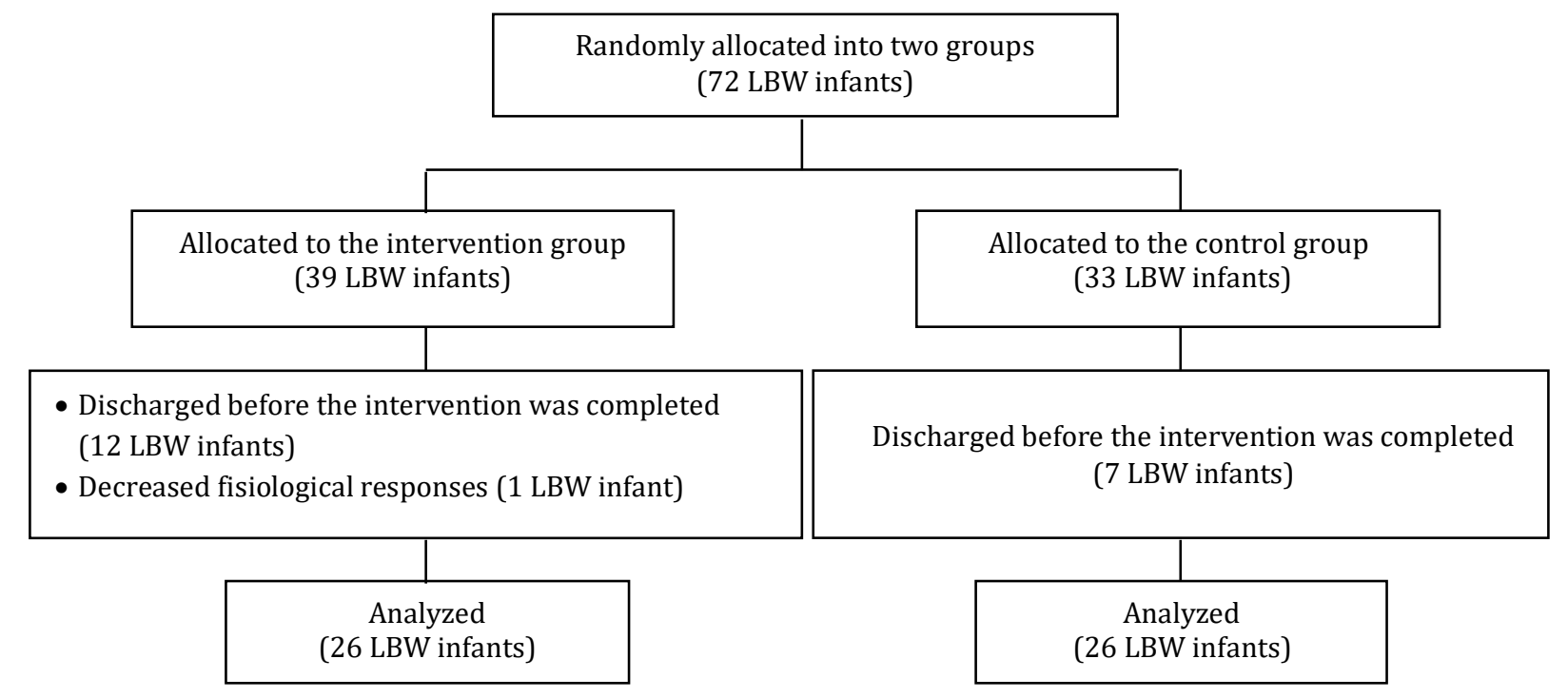

Figure 1. Enrollment and random allocation flowchart

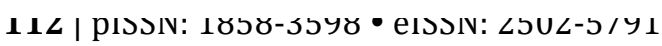


The interventions of auditory stimuli from Murottal Quran given to the LBW infants were Surah Ar-Rahman and Yasin using an MP3 and a mini-portable speaker 4 times a day for 20 minutes every 3 hours in 3 days. The intervention was started after touching time (changing diapers, giving drink/breast milk or another routine intervention, and interaction with the parents) by playing the Murottal Quran through the MP3 player and speaker placed in the incubator. The speaker was placed $10-15 \mathrm{~cm}$ from the baby's head (Efendi, Caswini, Rustina, Teguh, \& Iskandar, 2018). The first intervention was started at 9.30$10.30 \mathrm{WIB}$, the second intervention was started at 12.30-13.00 WIB, the third intervention was started at 15.30-16.30 WIB, and the fourth intervention was started at 18.30-19.30 WIB.

The weight was assessed at pre-intervention (baseline) on day 1 in intervention and control group. The infants' weight was measured on days 2, 3 and 4 after the intervention and on days 1 to 3 for the intervention and control groups. The precomfort assessment was assessed before the first intervention in two groups using a video recorder for two minutes on days 1,2 , and 3 . The video were taken within a distance of $30-40 \mathrm{~cm}$. The post-comfort assessment was conducted right after the fourth intervention of Murottal Quran on days 1, 2 and 3. The comfort was assessed by 3 experts with a Master's degree in pediatric nursing who have more than 3 years of experience of working in perinatology. The comfort observation sheet was completed after 3 days of the intervention.

This research was approved by Ethics Committee of Nursing Faculty, Universitas Indonesia, No. 16/UN2.F12.D/HKP.02.04/2019. Before conducting the research on LBWs that met the inclusion criteria, the researchers first met the parents and provided an explanation of the objectives, procedures and interventions that will be given to the LBWs. If the parents were willing, the researcher asked for approval and offered them an informed consent form.

A computer device was used to facilitate the data analysis in this study. The data normality test was measured using Shapiro Wilk. The analysis

Table 1. Respondent's Characteristics and the Homogeneity between the Two Groups

\begin{tabular}{|c|c|c|c|}
\hline Variable & $\begin{array}{c}\text { Intervention } \\
(n=26)\end{array}$ & $\begin{array}{l}\text { Control } \\
(n=26)\end{array}$ & p value \\
\hline \multicolumn{4}{|l|}{ Sex } \\
\hline Male & 14 & 12 & 1.000 \\
\hline Female & 12 & 14 & \\
\hline \multicolumn{4}{|l|}{ Nutrient type } \\
\hline Breast milk & 0 & 0 & 0.224 \\
\hline Formula milk & 7 & 7 & \\
\hline Mix & 19 & 19 & \\
\hline Birth weight (mean) & $1620.96\left(305.59^{*}\right)$ & $1552.31\left(313.42^{*}\right)$ & 0.918 \\
\hline \multicolumn{4}{|l|}{ Age (mean) } \\
\hline Gestasional age & $32.50\left(1.77^{*}\right)$ & $32.96(2.29 *)$ & 0.381 \\
\hline Chronological age & $5.65\left(5.78^{*}\right)$ & $8.69\left(8.33^{*}\right)$ & 0.024 \\
\hline \multicolumn{4}{|l|}{ Intervention (mean) } \\
\hline $\begin{array}{l}\text { Pain procedure before } \\
\text { intervention day } 1\end{array}$ & $0.96\left(1.11^{*}\right)$ & $0.73\left(0.78^{*}\right)$ & 0.394 \\
\hline $\begin{array}{l}\text { Pain procedure before } \\
\text { intervention day } 2\end{array}$ & $0.65\left(0.98^{*}\right)$ & $0.50\left(0.58^{*}\right)$ & 0.228 \\
\hline $\begin{array}{l}\text { Pain procedure before } \\
\text { intervention day } 3\end{array}$ & $0.65\left(0.85^{*}\right)$ & $0.38\left(0.49^{*}\right)$ & 0.090 \\
\hline
\end{tabular}

Table 2. Comfort and Weight Difference after the Intervention of Murottal Quran between the Two Groups

\begin{tabular}{lccccc}
\hline \multirow{2}{*}{ Variable } & \multicolumn{2}{c}{ Intervention Group (n=26) } & \multicolumn{2}{c}{ Control Group (n=26) } & p value \\
\cline { 2 - 4 } & Median & Min-Max & Median & Min-Max & \\
Comfort & & & & & \\
Day 1 & 9.50 & $6-19$ & 13.50 & $6-30$ & $0.014^{*}$ \\
Day 2 & 7.50 & $6-21$ & 13.00 & $6-29$ & $<0.001^{*}$ \\
Day 3 & 7.00 & $6-19$ & 16.50 & $6-30$ & $<0.001^{*}$ \\
& & & & & \\
Weight & & & & \\
Day 1 & 1530.00 & $1140-2120$ & 1445.00 & $1070-1920$ & 0.481 \\
Day 2 & 1535.00 & $1270-2130$ & 1465.00 & $1090-1920$ & 0.481 \\
Day 3 & 1545.00 & $1250-2120$ & 1460.00 & $1100-1980$ & 0.464 \\
\hline
\end{tabular}

Repeated Mann-Whitney test

Note: *significant at $\alpha(0.05)$ 
between the groups was generated using a repeated Mann Whitney test for the non-parametric testing (Dahlan, 2014).

\section{RESULTS}

The data for this study came from 52 LBW infants selected randomly for the intervention group $(n=26)$ and control group $(n=26)$. The respondents' characteristics for this study comprised of sex, birth weight, gestational age, chronological age, nutrient type, and treatment before the intervention. The findings show that the number of male respondents was 14 in the intervention group and that the number of females was 14 in the control group. The most frequent nutrient type was a mixture of breast milk and formula, while the average birth weight in intervention and control group were 1620.96 grams and 1552.31 grams respectively. The average gestational age in both the intervention and control groups was 32.50 weeks and 32.96 weeks respectively. The average chronological age in the intervention and control groups was 5.65 days and 8,69 days respectively. The pain procedure before the intervention in the intervention group indicated an average of 0.96 on day $1,0.65$ on day 2 , and 0.65 on day 3 . Meanwhile, in the control group, the average was 0.73 on day $1,0.50$ on day 2 , and 0.38 on day 3 . The characteristics between the groups showed a homogenous variation with a p value greater than 0.05. The characteristics and homogeneity can be seen in Table 1.

The result of the repeated Mann-Whitney test on comfort and weight in the Intervention and Control group on days 1, 2 and 3 after the intervention in the Murottal group can be seen in Table 2. The results showed there to be a significant difference in the comfort scale after the intervention between the intervention and control groups $(p>0.05)$ with a median score in the intervention group that was less than the median score in the control group. The analysis from the repeated Mann-Whitney test on the infant's weight between the intervention and control group on days 2, 3 and 4 did not show any significant difference after the intervention of Murottal Quran ( $p>0.05$ ).

\section{DISCUSSION}

\section{The Effects of Murottal Quran to Comfort}

Murottal Quran is a therapy that can reduce the level of stress because listening to and reading the Quran increases the alpha waves in the brain. This gives more of a relaxation effect than classical music (Zulkurnaini, Shilawani, Kadir, Murat, \& Isa, 2012). The results of this study showed there to be a significant difference in comfort between the intervention and control group after the auditory stimuli from Murottal Quran was conducted for three days. This finding was in line with the research conducted by Marofi et al (2018) who found there to be a significant difference in the pain intensity average in the neonates after being given Murottal Quran between the intervention and control groups in an intensive care unit. The treatment in an intensive care unit affects the brain, with one of the responses being triggering a stress response. The stress response activates the sympathetic nervous system and hypothalamus gland, in addition to the pituitary and adrenals (Anderson \& Patel, 2018).

According to Anderson and Patel (2018), the neonates in NICU that were exposed to music showed benefits related to the hypothalamus gland, pituitary, and adrenal (HPA). The sound of music could reduce the HPA stimuli by decreasing the cortisol level (Yamasaki et al., 2012). This finding was supported by Qiu et al (2017), who assessed 62 preterm infants related to the effect of music therapy on the infant pain profile, cortisol level, and $\beta$-endorfin. They showed there to be a decrease in pain score and increased $\beta$-endorfin after the music therapy was conducted for 2 weeks.

Another research study by Loewy, Stewart, Dassler, Telsey, and Homel (2013) involving 272 infants resulted in an improvement in their sleep condition and a quiet period for those who received music therapy. Keith, Russell, and Weaver (2009) conducted research on 22 infants in NICU and found that lullaby music significantly reduced the crying period after the music played.

Studies on the effect of Quran recitation on the physiological responses of neonates have also been conducted by other researchers. Several studies have showed there to be a significant difference in the physiological responses after receiving Murottal Quran therapy in neonates treated in NICU (Eskandari et al., 2012; Majidipour et al., 2018; Qolizadeh et al., 2018). The sound of the Quran could reduce the sympathetic nervous system activity in neonates, which can increase relaxation, reduce stress, and improve physiological responses such as the vital signs. Listening to Murottal Quran is one of the alternatives for neonates as 
it is a distraction from the varied stimuli in the NICU (Qolizadeh et al., 2018).

\section{The Effects of Murottal Quran on Weight}

According to (Yamasaki et al., 2012), music could influence the metabolic process due to the activation of the HPA system. This activation plays an important role in metabolism and energy balance. The cortisol produced by the HPA system triggers gluconeogenesis and glycogenesis that can trigger protein, fat, and carbohydrate catabolism. Stress hormones can reduce the gastric activity and motility, which then prolongs gastric emptying and disturbs nutrient absorption.

Music could reduce their cortisol level, which decreases HPA activity, alters the catabolism process, and increases the amount of growth hormones (Yamasaki et al., 2012). A similar thing was also stated by (Lin et al., 2007) who found that there was an increase in gastric myoelectric activity in the respondents who listened to music, which increased their gastric motility and speeded up gastric emptying.

This study showed no significant difference of weight between LBW infants who received auditory stimuli from Murottal Quran and those who did not. This finding was supported by Farhat, Amiri, Karbandi, and Esmaily (2010), who conducted research involving 44 very low weight birth infants with a gestational age of less than 34 weeks. They were given lullaby music over 8 days every day for 20 minutes. His study did not show there to be a significant difference in weight between the intervention and control groups. Another study (Standley, 2012) also supported the results of this study, which found that there was no significant weight difference in babies who received music therapy based on the meta-analysis effect of music therapy for babies in NICU.

This finding was different from the study by Auto, Amancio, and Lanza (2013) who conducted an analysis of the weight difference between the infants receiving music therapy over a 7 day intervention. In this study, the intervention was given over 3 days. A literature review related to the effect of music therapy in preterm babies showed that one of the positive effects of music on preterm babies was an increase in daily weight (Neal \& Lindake, 2008). The increase in their daily weight did not show a significant difference in this study because the average age was 5.65 days. According to Clark, Spitzer, and Olsen (2014), at 5-10 days old, the weight tended to remain the same and it would increase at 10-56 days old. The average of the respondent's age was less than 10 days. This is one of the reasons why this study did not yield significant results. The study by Auto, Amancio, and Lanza (2013) using a sample of 10-56 day old infants showed that there was a significant difference between the intervention and control group.

According to Standley (2012), birth weight was related to the effect of music therapy in neonates. This is based on the meta-analysis of music therapy on neonates in NICU. Her research showed that music therapy was not significant on infants with a birth weight above 1500 grams. This was in line with the finding of this study where the average birth weight of the respondents was 1552 grams and 1620 grams for the two groups. The analysis yielded no significant differences between the intervention and control group after receiving auditory stimuli in the form of Murottal Quran.

\section{CONCLUSION}

The finding of this study showed that auditory stimuli in the form of Murottal Quran is effective at improving the comfort of LBW infants treated in perinatology. In terms of weight, there was no significant difference. The auditory stimuli of Murottal Quran could improve the comfort of LBW infants during hospitalization.

The result of this study can be used as one of the supportive therapies to facilitate low birth weight and premature infant development. Further research should consider the infants' age and weight, and making the intervention duration more than 3 days in order to yield more significant result.

\section{REFERENCES}

Almadhoob, A., \& Ohlsson, A. (2015). Sound reduction management in the neonatal intensive care unit for preterm or very low birth weight infants. Cochrane Database of Systematic Reviews, 1 , CD010333. https://doi.org/10.1002/14651858.CD010333.p ub2

Anderson, D. E., \& Patel, A. D. (2018). Infants born preterm, stress, and neurodevelopment in the neonatal intensive care unit: might music have an impact? Developmental Medicine \& Child Neurology, 60(3), 256-266. https://doi.org/10.1111/dmcn.13663

Auto, L., Amancio, O. M. S., \& Lanza, F. de C. (2013). The effect of music on weight gain of preterm infants older than 32 weeks: A randomized 
clinical trial. Rev Paul Pediatr, 31(3), e293-299. http://dx.doi.org/10.1590/0103-058231369512

Bouza, H. (2009). The impact of pain in the immature brain. The Journal of Maternal and Neonatal Medicine, 22(9), 722-732. https://doi.org/10.3109/14767050902926962

Boxwell, G. (2010). Neonatal intensive care nursing (2nd). USA: Taylor \& Francis elibrary

Brown, G. (2009). NICU noise and the preterm infant. Neonatal Network, 28(3), 165-173. https://doi.org/10.1891/0730-0832.28.3.165

Clark, R. H., Spitzer, A. R., \& Olsen, I. E. (2014). Assessment of neonatal growth in prematurely born infants. Clinics in Perinatology, 41(2), 295307. https://doi.org/10.1016/j.clp.2014.02.001

Dahlan, M.S. (2014). Statistik untuk kedokteran dan kesehatan: Deskriptif, bivariat, dan multivariat, dilengkapi aplikasi menggunakan SPSS edisi 6. Jakarta: Epidemiologi Indonesia

Efendi, D., Caswini, N., Rustina, Y., Teguh, R. A., \& Iskandar, P. (2018). Combination of mother therapeutic touch ( MTT ) and maternal voice stimulus ( MVS ) therapies stabilize sleep and physiological function in preterm infants receiving minor invasive procedures, 24, 318324. https://doi.org/10.1016/j.jnn.2018.08.001

Eskandari, N., Keshavars, M., Ashayeri, H., Jahdi, F., \& Hosseini, A. F. (2012). Quran recitation: Short term and related factor in preterm newborn. Research Journal of Medical Sciences, 6(3), 148153. DOI: $10.3923 /$ rjmsci.2012.148.153

Farhat, A., Amiri, R., Karbandi, S., \& Esmaily, H. (2010). The effect of listening to lullaby music on physiologic response and weight gain of premature infants . Journal of Neonatal-Perinatal Medicine, 3, 103-107. https://doi.org/10.3233/NPM-2010-0101

Hall, S. L., \& Sanders, M. R. (2018). Trauma-informed care in the newborn intensive care unit: promoting safety, security and connectedness. Nature Publishing Group, 38(1), 3-10. https://doi.org/10.1038/jp.2017.124

Keith, D. R., Russell, K., \& Weaver, B. S. (2009). The Effects of music listening on inconsolable crying in premature infants medical center of central Georgia. Journal of Music Therapy, 46(3), 191203. DOI: $10.1093 / \mathrm{jmt} / 46.3 .191$

Koo, T. K., \& Li, M. Y. (2016). A guideline of selecting and reporting intraclass correlation coefficients for reliability research. Journal of Chiropractic Medicine, 15(2), 155-163. https://doi.org/10.1016/j.jcm.2016.02.012

Lin, H., Chang, W., Chu, H., Huang, T., Chao, Y., \& Hsieh, T. (2007). Effects of music on gastric myoelectrical activity in healthy humans. International Journal of Clinical Practice, 61(7), 1126-1130. https://doi.org/10.1111/j.17421241.2006.01090.x

Loewy, J., Stewart, K., Dassler, A., Telsey, A., \& Homel, P. (2013). The effects of music therapy on vital signs, feeding, and sleep in premature infants.
Pediatrics, 131(5), 902-918. https://doi.org/10.1542/peds.2012-1367

Majidipour, N., Nirouzad, F., Madmoli, Y., Sarrafzade, S., Aghababaeian, H., \& Borujeni, S. H. (2018). The effect of holy Quran recitation on the physiological responses of premature infants during phlebotomy: A randomized clinical trial. International Journal of Pediatrics, 6(55), 78697881.

https://doi.org/10.22038/ijp.2017.24203.2038

Marofi, M., Abedini, F., Shirazi, M., Badiei, Z., Baghersad, Z., \& Nikobakht, F. (2018). Effect of the Sound of the Holy Quran on the Physiological Responses and Pain Caused by Blood Sampling from the Heels of Hospitalized Neonates at the Neonatal Intensive Care Unit. Iranian Journal of Neonatology, 9(3), 57-63. https://doi.org/10.22038/ijn.2018.28102.1376

Neal, D. O., \& Lindak, I. I. (2008). Music as a nursing intervention for preterm infants in the NICU. Neonatal Network, 27(5), 319-327. Doi: 10.1891/0730-0832.27.5.319

Pickler, R., Mcgrath, J. M., Reyna, B. A., Tubbs-cooley, H. L., Best, A. M., Lewis, M., ... Wetzel, P. A. (2013). Effects of the neonatal intensive care unit environment on preterm infant oral feeding. Research \& Reports in Neonatology, (3), 15-20. https://doi.org/10.2147/RRN.S41280

Qiu, J., Jiang, Y., Li, F., Tong, Q., Rong, H., \& Cheng, R. (2017). Effect of combined music and touch intervention on pain response and $\beta$-endorphin and cortisol concentrations in late preterm infants. BMC Pediatrics, 17(38),1-7. https://doi.org/10.1186/s12887-016-0755-y

Qolizadeh, A., Myaneh, Z. T., \& Rashvand, F. (2018). Investigating the effect of listening to the holy Qur'an on the physiological responses of neonates admitted to neonatal intensive care unit: A pilot study. Advances in Integrative Medicine. Article in Press. https://doi.org/10.1016/j.aimed.2018.08.004

Rilla, E. V., Ropi, H., \& Sriati, A. (2014). Terapi murottal efektif menurunkan tingkat nyeri. Jurnal Keperawatan Indonesia, 17(2), 74-80.

Rustina, Y. (2015). Bayi prematur: Perspektif keperawatan. Jakarta: CV Sagung Seto.

Standley, J. M. (2012). Music therapy research in the NICU: An updated meta-analysis. Neonatal Network, 31(5), 311-316. DOI: 10.1891/07300832.31.5.311

Valizadeh, S., Hosseini, M. B., Alavi, N., Asadollahi, M., \& Kashefimehr, S. (2013). Assessment of sound levels in a Neonatal Intensive Care Unit in Tabriz. J Caring Sci, 2(1), 19-26. https://doi.org/10.5681/jcs.2013.003

van Dijk, M., Roofthooft, D. W. E., \& Anand, K. J. S. (2009). Taking up the challenge of measuring prolonged pain in ( premature) neonates the COMFORTneo scale seems promising. Clin J Pain, 25(7), 607-616. DOI: 10.1097/AJP.0b013e3181a5b52a 
Wachman, E. M., \& Lahav, A. (2011). The effects of noise on preterm infants in the NICU. Arch Dis Child Fetal Neonatal Ed, 96(4), F305-9. https://doi.org/10.1136/adc.2009.182014

Yamasaki, A., Booker, A., Kapur, V., Tilt, A., Niess, H., \& Keith D Lillemoe, Andrew L Warshaw, C. C. (2012). The impact of music on metabolism. Nutrition, 28(11-12),

1075-1080. https://doi.org/10.1016/j.nut.2012.01.020
Zulkurnaini, N. A., Shilawani, R., Kadir, S. A., Murat, Z. H., \& Isa, R. M. (2012). The comparison between listening to Al-Quran and listening to classical music on the brainwave signal for the alpha band. IEEE Computer Society, 181-186. https://doi.org/10.1109/ISMS.2012.60 